\title{
Evolution Of Fair Business Performance As A Tool Of Marketing In Spain
}

María Cordente-Rodríguez, University of Castilla-La Mancha, Spain

Juan-Antonio Mondéjar-Jiménez, Ph.D., University of Castilla-La Mancha, Spain Juan-Carlos Gázquez-Abad, Ph.D., University of Almería, Spain

\begin{abstract}
Although the distance communication systems have been developed in the last years thanks to the development of communication and information technologies, recent studies argue that simple ways of communication like fairs maintain and increase their weigh cause of their profitability.

In this way the fairs represent an important communication platform, whose use is generalized in the all economic areas.

The aim of this paper is analyze the evolution of fair business in Spain, in the period 2002-2009, to solve two important questions which revolve about the efficiency of this communication tool and its power to maintain and establish new business relationship.

For this, this paper analyzes the main characteristics or indicators of fair business, such as number of celebrated events, areas of interest, number of exhibitors or the number of attendees, from the information of Spanish Association of Fairs.
\end{abstract}

Keywords: Trade Fairs; Communication; Efficiency

\section{INTRODUCTION}

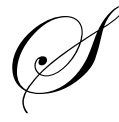

trategic marketing decisions do not just require developing a good product, giving it an attractive price and making it available to consumers, but also that companies communicate this to its present and potential customers and to the general public, becoming communicators and promotors of their products.

Marketing communication can be carried out using five main tools: advertising (communication media, information brochures, etc.), sales promotion (short-term sales stimulation), public relations (talks, conferences, etc.), personal selling (contact with the customer) and direct marketing; and the choice of one tool or another will depend on a series of factors which will determine their suitability or desirability in each case:

- $\quad$ Available resources.

- $\quad$ Type of product to be sold.

- $\quad$ Market characteristics.

- $\quad$ Type of marketing strategy used.

- $\quad$ Stage of the buying decision process.

- $\quad$ Stage of the product life cycle.

And within each communication tool, there are various communication platforms (Table 1): catalogues, samples, sales, packaging, trade fairs,...; (Kotler, 2006).

One of these communication platforms is fairs, which allow the combined use of three communication tools: sales promotion, public relations and personal selling. 
So in spite of the development remote communication systems have experienced in recent years because of the progress of information and communication technology, simpler forms of communication, allowing face-to-face contact and more personal communication, carried out sporadically and concentrated in time and space, still have their place and are even becoming more important.

Table 1: Communication tools

\begin{tabular}{|c|c|c|c|c|}
\hline Advertising & Sales promotion & Public relations & Direct marketing & Personal selling \\
\hline Print and broadcasting & $\begin{array}{l}\text { Competitions, games, } \\
\text { lotteries and draws }\end{array}$ & Press & Catalogues & Sales presentations \\
\hline Packaging & Discount/gift vouchers & Conferences & Direct mailing & Meetings \\
\hline Insertions in packaging & Free samples & Seminars & Telesales & Incentive schemes \\
\hline Cartoons & Fairs & Annual reports & E-commerce & Free samples \\
\hline $\begin{array}{l}\text { Brochures and domestic } \\
\text { magazines }\end{array}$ & Exhibitions & Charity & Television buying & Fairs \\
\hline Posters and leaflets & Demonstrations & Sponsorship & Fax-mail & \\
\hline Directories & Returns & Publications & E-mail & \\
\hline Ad reprints & Sales & Social relations & Voice box & \\
\hline Hoardings & Low-cost finance & Lobbies & & \\
\hline Shop windows & Meetings & Media relations & & \\
\hline Point-of-sale material & Aid to sellers & Company magazine & & \\
\hline Audiovisual material & Continuity programmes & Events & & \\
\hline Symbols and logos & $\begin{array}{l}\text { Agreements with } \\
\text { distributors }\end{array}$ & Fairs & & \\
\hline Video tapes & & & & \\
\hline
\end{tabular}

The purpose of this study is to examine the use of trade fairs as a market variable and the progress of the main indicators of its profitability in the period 2002-2009.

\section{FAIRS BUSINESS AS A TOOL OF MARKETING}

A trade fair or show is a regular event at which companies or organizations with the same commercial activity exhibit their products or services to the visiting public. And it is a tool for communication, and exchange of information and knowledge among the different participants.

It is the oldest instrument of communication (Jiménez, Cazorla and Linares, 2002) going back to the Phoenician civilization (over $1200 \mathrm{BC}$, in the form of markets) and an important tool for the communication and exhibition of market offer, as well as an instrument for contact with customers (Gázquez and Jiménez, 2002); i.e., it is a communication tool used in both sales promotion and personal selling.

Other approaches, though (Rodríguez, De La Ballina and Santos, 1997) consider that fairs are used as an element to improve company image and communicate that image to the market, so considering it a public relations tool.

These are the differences between a trade fair and other promotion activities (Jiménez, Cazorla and Linares,

- The only form of promotion where the buyer goes to the seller, so obtaining an advantage which is the customer's predisposition to listen, be attended to and get information.

- It allows contact with a large number of customers in a short time.

- $\quad$ Access to customers and businessmen who are not accessible under normal sales conditions.

- Simultaneous intervention of various communication tools: advertising, sales promotion, personal selling and public relations, increasing the possibility of the communication being effective.

- $\quad$ And the intervention of other marketing variables: product, price and distribution, making use of all marketing variables. 
Attendance and participation in trade fairs is considered one of the most useful tools, because they are living trading operation markets, where the best information in the sector is found, and which provide the meeting point between businesses and customers specialized in the sector, favouring the exchange of trends and opinions (Muñiz, 2010). In addition, participation in a fair is one of the main marketing tools allowing businessmen to enter, research or consolidate themselves in markets (Navarro, 2001). According to this approach, fair policy is a combination of various policies, such as sales, product, communication, distribution and market research policies (Munuera, Ruiz, Hernández and Más, 1993), so making it a multidisciplinary marketing tool (Gázquez and Jiménez, 2002).

It is also an effective, low-cost medium for accessing new customers, and so a cost-effective tool. It is considered that a seller maintains on average direct, personal contact with more current and potential customers than in six months of normal work (Planner Group).

So in contrast to the traditional classification of fairs as a communication tool, the multidimensional nature of this tool is prevailing, because of its contribution to the other marketing variables:

- $\quad$ Price: existence of a fair price and discounts offered to visitors.

- $\quad$ Product: new products are presented, with demonstrations of them, and ideas collected from fair visitors for the creation of new products.

- Distribution: the fair is a place of distribution and also an ideal place for establishing relationships with distribution channel intermediaries.

This brings us to a definition of fair (Puchalt, 2001) as "a marketing instrument, the putting into practice of which allows the companies and professionals who make use of it to carry out different functions to achieve their objectives: communication, promotion, sales, relations, information exchange, research, customer loyalty promotion, positioning, distribution, training, market and product testing, among others," in which the multidimensional nature of fairs is confirmed.

Fairs allow participating companies to carry out a series of functions (Rubalcaba and Cuadrado, 1994):

- Commercial function: sales and also the creation and consolidation of commercial distribution networks.

- $\quad$ Exhibition function: a profitable alternative to traditional advertising processes.

- $\quad$ Communication function: the purpose of this is put supply and demand in contact with each other.

- $\quad$ Other functions: encourage competition between companies and a vehicle for publicising innovations.

Therefore, among the reasons and objectives a company has for being an exhibitor, not only those related with the communication policy but also with product, price and distribution are indicated. These are the main reasons according to a study by Gázquez and Jiménez (2002):

- $\quad$ Increase market share: increase sales and market share.

- $\quad$ Market prospecting: to gain new consumers and see market acceptance of the company's products.

- Image: improve positioning and the sector and customers' perception of the sector.

But giving greatest priority to the profitability criterion (Jiménez, Cazorla and Linares, 2002).

On the other hand, the main reasons for being a trade fair visitor include getting to know products and services, getting information about the market and competition and finding out about technological development.

In spite of the growth of the fair sector in recent years, one matter concentrating the interest of studies is obtaining the results of their participation as a justification of the effort and investment made. 
One study (Marketing News, 2006) concentrates on the analysis of profitability of communication actions from the opinion of 700 managers from North America, Europe and Asia. The overall results (Table 2) show that trade fair activity is considered the tool offering the highest profitability in the different geographic areas analysed, being most highly valued by managers from Asia, followed by those from Europe and finally North America.

Table 2: Managers who value the profitability of marketing actions most highly (\%)

\begin{tabular}{|l|c|c|c|c|}
\hline \multicolumn{1}{|c|}{ Tools of marketing } & Total & North America & Europe & Asia-Pacific \\
\hline Fairs & 23 & 19 & 23 & 32 \\
\hline Printed advertising & 10 & 9 & 7 & 17 \\
\hline Non-printed advertising & 7 & 7 & 5 & 10 \\
\hline Sales promotion & 9 & 8 & 11 & 10 \\
\hline Public relations & 15 & 16 & 14 & 15 \\
\hline Electronic marketing & 12 & 17 & 13 & 5 \\
\hline Direct marketing & 13 & 16 & 14 & 7 \\
\hline
\end{tabular}

Source: Marketing News, 2006.

Another study carried out in 2003 on 250 members of the US Business Marketing Association (Business Marketing Association Survey, 2003) examines the level of investment made in different marketing tools to support product sales. The results showed that managers on average dedicated the highest proportion of their budget to participation in trade fairs (18.6\%), followed by $13.8 \%$ to advertising in special interest press, $13.5 \%$ to Internet and other electronic media, $10.9 \%$ to sales promotion, $10.8 \%$ to public relations, $5.6 \%$ to merchandising, $4.1 \%$ to market research, 3.2\% to advertising in the general interest press and 19.6\% to other tools (Stevens, 2005).

\section{FAIR ACTIVITY IN SPAIN}

In this context, two questions arise: are trade fairs still an effective instrument for communicating the company's commercial offer? And has their power to establish new relationships or maintain them been reduced in favour of new technologies?

Europe is considered the greatest world power in terms of fair activity, concentrating over $50 \%$ of the world fair market (Puchalt, 2008). In addition, it has the highest available covered exhibition space capacity, the largest fair grounds and the main organizers.

The Spanish fair sector was very dynamic in the period 1990-2000, both in terms of the number of shows held and of exhibitors and visitors (Jiménez, Cazorla and Linares, 2002), so becoming an excellent tool for product promotion and an investment rather than an expense.

The progress of the fair business runs parallel to the general economic state of the country, but will also depend on the progress of the sector in question, a fact which will be reflected in the sector growth over the period studied, 2002-2009.

To study the situation over the last eight years, we will use the information provided by the Spanish Fair Association (AFE), which collects detailed information on fair activity from the its associated institutions, currently 58 members, 49 of which are public or private fair organizers and the other 9 are partner members.

The trend in the number of fairs held a year in Spain is upwards since 2002, with a drop in 2008 which was reversed in 2009 (Table 3); in terms of the number of direct exhibitors, the trend is similar, upward since the year 2000, with a drop in 2008 which continued in 2009. 
Table 3: Evolution of fair activity

\begin{tabular}{|l|c|c|}
\cline { 2 - 3 } \multicolumn{1}{c|}{} & Fairs & Direct exhibitors \\
\hline $\mathbf{2 0 0 2}$ & 419 & 64.664 \\
\hline $\mathbf{2 0 0 3}$ & 423 & 66.866 \\
\hline $\mathbf{2 0 0 4}$ & 423 & 68.349 \\
\hline $\mathbf{2 0 0 5}$ & 441 & 69.251 \\
\hline $\mathbf{2 0 0 6}$ & 471 & 74.382 \\
\hline $\mathbf{2 0 0 7}$ & 507 & 79.111 \\
\hline $\mathbf{2 0 0 8}$ & 480 & 76.476 \\
\hline $\mathbf{2 0 0 9}$ & 488 & 60.974 \\
\hline
\end{tabular}

Source: the authors from AFE data

Looking at the nature of fairs (Table 4), professional fairs have traditionally predominated, followed by those aimed at the general public and finally mixed fairs. However, this trend has changed since 2006, and fairs aimed at the general public now predominate to the detriment of fairs for professionals.

Table 4: Evolution of fairs according to target audience (\%)

\begin{tabular}{|l|c|c|c|c|c|c|c|c|}
\cline { 2 - 9 } \multicolumn{1}{c|}{} & $\mathbf{2 0 0 2}$ & $\mathbf{2 0 0 3}$ & $\mathbf{2 0 0 4}$ & $\mathbf{2 0 0 5}$ & $\mathbf{2 0 0 6}$ & $\mathbf{2 0 0 7}$ & $\mathbf{2 0 0 8}$ & $\mathbf{2 0 0 9}$ \\
\hline General public & 33,49 & 34,61 & 35,36 & 36,40 & 40,13 & 41,78 & 41,46 & 41,80 \\
\hline Professional public & 40,83 & 39,10 & 42,86 & 41,80 & 36,81 & 38,61 & 34,17 & 34,02 \\
\hline Mixed public & 25,69 & 26,29 & 21,78 & 21,80 & 23,06 & 19,60 & 24,38 & 24,18 \\
\hline
\end{tabular}

Source: the authors from AFE data

If you look at fairs according to their content by sector, it is hard to find an economic activity or sector which does not have a fair or is represented in one (Puchalt, 2008); in 2008, the level of sector separation increased, going from 12 to 16 categories, allowing the trend in each sector to be seen with greater precision. In contrast to this broad sector classification, in recent years fairs have become highly specialized, and 160 sectors or subsectors can be distinguished (Puchalt, 2001).

The trend observed (Table 5) is a progressive abandonment of general fairs in favour of fairs specific to particular areas of activity (Gámir, 1999). But more than specific fairs, the abandonment has been in fair of mixed fairs involving various branches of activity.

Table 5: Fair activity according to sector category (\%)

\begin{tabular}{|l|c|c|c|c|c|c|c|c|}
\cline { 2 - 10 } \multicolumn{1}{c|}{} & $\mathbf{2 . 0 0 2}$ & $\mathbf{2 0 0 3}$ & $\mathbf{2 . 0 0 4}$ & $\mathbf{2 . 0 0 5}$ & $\mathbf{2 . 0 0 6}$ & $\mathbf{2 . 0 0 7}$ & $\mathbf{2 . 0 0 8}$ & $\mathbf{2 . 0 0 9}$ \\
\hline General fairs & 4,81 & 5,39 & 7,03 & 6,29 & 5,53 & 5,33 & 5,00 & 5,33 \\
\hline Trade fairs & 95,19 & 94,61 & 92,97 & 86,52 & 88,27 & 85,40 & 82,71 & 82,17 \\
\hline Mixed fairs & 0,00 & 0,00 & 0,00 & 7,19 & 6,19 & 9,27 & 12,29 & 12,50 \\
\hline Total & 100,00 & 100,00 & 100,00 & 100,00 & 100,00 & 100,00 & 100,00 & 100,00 \\
\hline
\end{tabular}

Source: the authors from AFE data

A study by Jiménez and Pemartín (2008) analysed the situation of fair activity in the various sectors in relation to the life-cycle phase. This study highlights the importance of the leisure, sport and tourism sector, the one with the greatest short-term projection, because of the growth trend in both number of events and of exhibitors and visitors, in the period 1995-2005.

Centering on the growth by sector of fair activity up to 2007 (Table 6), leisure, sport and tourism fairs (Category B9) encompass the majority of events held, followed by fairs of apparel (fashion and complements: B3), other commercial and industrial sectors (B10) and communication and new technologies (B8) in fourth place. From 2008 on (Table 7), tourism, sport and leisure fairs (B12) is the most frequent category, with a growth trend, followed by automotion fairs (B9) and fashion and complements (B3), in third place.

With regard to the growth of mixed fairs involving various branches of activity, they appeared in 2005, and have undergone positive growth throughout the period studied. 
Table 6: Evolution of fair by sectors $2002-2007(\%)$

\begin{tabular}{|l|c|c|c|c|c|c|}
\hline \multicolumn{1}{l|}{} & $\mathbf{2 0 0 2}$ & $\mathbf{2 0 0 3}$ & $\mathbf{2 0 0 4}$ & $\mathbf{2 0 0 5}$ & $\mathbf{2 0 0 6}$ & $\mathbf{2 0 0 7}$ \\
\hline $\begin{array}{l}\text { A: General fairs } \\
\text { B1: Agriculture, horticulture, livestock (except horses and fighting bulls), }\end{array}$ & 5,81 & 5,39 & 7,03 & 6,29 & 5,53 & 5,33 \\
\hline B2: Food, drink, catering & 5,39 & 5,62 & 3,60 & 3,76 & 6,11 \\
\hline $\begin{array}{l}\text { B3: Apparel, footwear, fashion, leather, jewellery, costume jewellery, } \\
\text { accessories and complements }\end{array}$ & 11,90 & 10,79 & 10,30 & 10,56 & 9,96 & 8,48 \\
\hline $\begin{array}{l}\text { B4: Construction, public works and municipal equipment, swimming } \\
\text { pools, housing sector, mining, their equipment and raw materials }\end{array}$ & 6,41 & 4,94 & 6,79 & 6,52 & 6,64 & 4,93 \\
\hline B5: Furniture, lighting, home appliances, gifts & 5,26 & 5,39 & 4,68 & 4,94 & 5,09 & 4,34 \\
\hline $\begin{array}{l}\text { B6: Health, healthcare, pharmacy, orthopaedics and rehabilitation, } \\
\text { hygiene, cosmetics, environment, funeral services, safety and accident } \\
\text { prevention }\end{array}$ & 6,86 & 7,42 & 6,56 & 6,52 & 6,86 & 6,90 \\
\hline $\begin{array}{l}\text { B7: Automotion (new and second hand vehicles), traffic, transportation, } \\
\text { logistics, service stations and their equipment }\end{array}$ & 6,18 & 6,52 & 8,20 & 8,09 & 8,41 & 9,07 \\
\hline $\begin{array}{l}\text { B8: Communication and new technologies, training, information, office } \\
\text { supplies, stationery, printing, graphic arts, signage, books }\end{array}$ & 9,38 & 6,97 & 6,56 & 7,19 & 6,64 & 7,30 \\
\hline $\begin{array}{l}\text { B9: Sport, toys, games, entertainment, music, DIY, hobbies, leisure, } \\
\text { tourism, pets, dog shows, horse shows and bull fights, children's fairs, } \\
\text { pensioners' fairs, Christmas fairs }\end{array}$ & 17,62 & 23,60 & 22,48 & 19,55 & 22,79 & 18,54 \\
\hline $\begin{array}{l}\text { B10: Other commercial and industrial sectors. Franchises, business } \\
\text { organization and management, consultants, audits and consulting, } \\
\text { financial services, insurance, science and technology and their equipment, } \\
\text { wedding services and banquets }\end{array}$ & 11,67 & 9,66 & 7,73 & 8,09 & 6,86 & 7,50 \\
\hline C: Art, crafts, antiques and collecting (since 2003: Other fairs) & 9,15 & 9,21 & 7,73 & 6,97 & 6,42 & 5,72 \\
\hline Mixed sectors & 0,00 & 0,00 & 0,00 & 7,19 & 6,19 & 9,27 \\
\hline Total & 100,00 & 100,00 & 100,00 & 100,00 & 100,00 & 100,00 \\
\hline
\end{tabular}

Source: the authors from AFE data

In terms of growth by sector in the two most recent years (2008 and 2009), the greater higher separation of the classification of sector categories gives more precise data on fair activity (Table 7). So Category B12, Tourism, sport, leisure and their equipment, is the one which includes the largest number of fairs, undergoing positive growth like the figure for fairs overall. The category of mixed fairs continues to grow, reaching its peak in 2009 of the last eight years.

Table 7: Evolution of fair by sectors 2008-2009 (\%)

\begin{tabular}{|c|c|c|}
\hline & 2.008 & 2.009 \\
\hline A: General fairs (samples and multiple sectors) & 5,00 & 5,33 \\
\hline B1: Agriculture, livestock, horticulture, flower-growing, fishing, forest industry and their equipment & 5,00 & 5,94 \\
\hline B2: Food, drink, catering and their equipment & 4,79 & 7,58 \\
\hline $\begin{array}{l}\text { B3: Fashion, footwear, leather, clothes, textiles, costume jewellery, jewellery, accessories, complements } \\
\text { and their equipments }\end{array}$ & 8,13 & 9,43 \\
\hline B4: Construction, public works, mining, their equipment and materials & 4,79 & 2,87 \\
\hline B5: Real estate & 1,46 & 2,46 \\
\hline B6: Decoration, furniture, lighting, gifts, office/home appliances and equipment and their equipment & 4,79 & 3,89 \\
\hline B7: Health, healthcare, pharmacy, biotechnology, cosmetics, safety, hygiene and risk prevention & 5,00 & 4,51 \\
\hline B8: Environment, energy and their equipment & 2,71 & 2,66 \\
\hline B9: Automotion, traffic, transportation, logistics and their equipment & 10,63 & 9,43 \\
\hline B10: Comunication, computing, telecommunications, audio-visual, multimedia and their equipment & 2,08 & 2,25 \\
\hline B11: Culture, education, training, employment and their equipment & 5,00 & 4,10 \\
\hline B12: Tourism, sport, leisure and their equipment & 17,29 & 18,03 \\
\hline B13: Art, crafts, auctions, antiques and their equipment & 5,00 & 4,51 \\
\hline B14: Other industrial sectors, subcontractors and their equipment & 1,67 & 1,64 \\
\hline B15: Other commercial and service sectors and their equipment & 4,38 & 2,87 \\
\hline Mixed sectors & 12,29 & 12,50 \\
\hline Total & 100,00 & 100,00 \\
\hline
\end{tabular}

Source: the authors from AFE data 
With regard to location, the number of cities or institutions which have held fairs increased throughout the period studied (Table 8). The highest number was reached in 2008, with 47 cities or institutions.

Table 8: Evolution of fair cities or institutions (2002-2009)

\begin{tabular}{|l|c|c|c|c|c|c|c|c|}
\cline { 2 - 10 } \multicolumn{1}{c|}{} & $\mathbf{2 0 0 2}$ & $\mathbf{2 0 0 3}$ & $\mathbf{2 0 0 4}$ & $\mathbf{2 0 0 5}$ & $\mathbf{2 0 0 6}$ & $\mathbf{2 0 0 7}$ & $\mathbf{2 0 0 8}$ & $\mathbf{2 0 0 9}$ \\
\hline Cities/Fairs & 36 & 38 & 40 & 43 & 44 & 45 & 47 & 46 \\
\hline
\end{tabular}

Source: the authors from AFE data

Study of the main fair cities or institutions shows that the five main fair centres in 2002 (Table 9) were IFEMA in Madrid, Fair of Barcelona, Fair of Valencia, the Casa de Campo in Madrid and Sevilla. In 2009 they were IFEMA, Fair of Barcelona, Fair of Valencia, Zaragoza and Elche.

Table 9: Evolution of fairs according to city or institution (2002-2009)

\begin{tabular}{|l|c|c|c|c|c|c|c|c|}
\multicolumn{1}{c|}{} & $\mathbf{2 0 0 2}$ & $\mathbf{2 0 0 3}$ & $\mathbf{2 0 0 4}$ & $\mathbf{2 0 0 5}$ & $\mathbf{2 0 0 6}$ & $\mathbf{2 0 0 7}$ & $\mathbf{2 0 0 8}$ & $\mathbf{2 0 0 9}$ \\
\hline Madrid IFEMA & 71 & 71 & 75 & 71 & 84 & 79 & 81 & 71 \\
\hline Fair of Barcelona & 55 & 51 & 44 & 54 & 47 & 56 & 40 & 52 \\
\hline Fair of Valencia & 36 & 42 & 37 & 42 & 31 & 39 & 29 & 38 \\
\hline Madrid Casa Campo & 25 & 23 & 7 & 6 & 5 & 0 & 0 & 0 \\
\hline Sevilla & 22 & 21 & 18 & 10 & 15 & 14 & 13 & 14 \\
\hline Bilbao BEC & 18 & 20 & 18 & 17 & 20 & 23 & 16 & 19 \\
\hline Elche & 16 & 21 & 22 & 24 & 24 & 27 & 26 & 28 \\
\hline Santa Cruz de Tenerife & 15 & 13 & 8 & 9 & 8 & 10 & 9 & 8 \\
\hline Vigo IFEVI & 15 & 16 & 9 & 8 & 9 & 2 & 3 & 3 \\
\hline Ourense & 13 & 12 & 11 & 10 & 10 & 11 & 9 & 9 \\
\hline Valladolid & 12 & 10 & 11 & 10 & 14 & 12 & 11 & 12 \\
\hline Zaragoza & 12 & 8 & 16 & 16 & 11 & 30 & 36 & 31 \\
\hline Jaén & 8 & 6 & 9 & 6 & 8 & 12 & 11 & 10 \\
\hline Palma de Mallorca & 10 & 12 & 9 & 11 & 11 & 13 & 16 & 17 \\
\hline Málaga & 0 & 0 & 13 & 16 & 15 & 15 & 17 & 15 \\
\hline Lleida & 9 & 8 & 10 & 11 & 12 & 14 & 12 & 13 \\
\hline
\end{tabular}

Source: the authors from AFE data

Notable points are the decline of the Casa de Campo in Madrid which began in 2004 until it disappeared altogether in 2007, and of the IFEVI in Vigo in 2005, a situation which worsened in 2007, being reduced to two exhibitions held; the forceful appearance of Malaga in 2004; and the big leap by Zaragoza in 2007, which in 2008 surpassed the Fair of Valencia, which had been the third strongest fair institution since 2002, after the Fair of Barcelona and the IFEMA ground in Madrid, in first place.

With regard to the number of countries taking part in fairs, although most are fairs in which two or more countries take part, the general trend observed in the 2002-2009 period is an increase in fairs with the participation of a single country (Table 10).

Table10: Evolution of participating countries (\%)

\begin{tabular}{|l|c|c|c|c|c|c|c|c|}
\hline Countries & $\mathbf{2 0 0 2}$ & $\mathbf{2 0 0 3}$ & $\mathbf{2 0 0 4}$ & $\mathbf{2 0 0 5}$ & $\mathbf{2 0 0 6}$ & $\mathbf{2 0 0 7}$ & $\mathbf{2 0 0 8}$ & $\mathbf{2 0 0 9}$ \\
\hline One & 27,46 & 34,83 & 27,87 & 33,71 & 37,61 & 37,08 & 45,83 & 40,79 \\
\hline Several & 72,54 & 65,17 & 72,13 & 66,29 & 62,39 & 62,92 & 54,17 & 59,21 \\
\hline
\end{tabular}

Source: the authors from AFE data 


\section{CONCLUSIONS}

The first conclusion to be drawn is that fair policy is not only considered a communication tool but as a combination of various policies (sales, product, communication, distribution and market research) which maximizes the benefit and usefulness of participation in them for exhibitors, for it allows them not only to publicize their activity but also to find out market trends, launch new products and even sell them.

This tool shows the main reasons exhibitors had given for participating in fairs, namely to increase market share (they have access to a large public), market prospecting (in terms of winning new customers and gaining acceptance of their products among them) and, finally, image and position.

The non-seasonal nature of fair dates contributes to the cities holding the events receiving an important flow of visitors in low-season periods, helping boost destinations and deseasonalisation of tourist demand.

The trend observed of holding increasingly specialized fairs in certain areas of activity and the abandonment of general fairs allows specialized fairs to be considered an interesting marketing option with a view to companies' future; the interesting thing is to specialize in specific sectors, allowing better knowledge of sectors and of the activity and giving better results from fair participation.

With regard to the number of participating countries, it would be interesting to get the highest possible participation, which would help both exhibitors and visitors to obtain the best results.

A limitation to the study which should be pointed out is that it is part of a broader research project, of which future lines of research are to increase the number of variables studied to measure the efficiency of participation in trade fairs, such as the number of people entering, the number of passes, domestic and international visitors or the net area dedicated to the activity, as well as detailed analysis of fair activity in each sector, including the tourist sector, which has become the most representative category in the trade fair business as a whole.

\section{AUTHOR INFORMATION}

María Cordente-Rodríguez, Degree in Business Administration by University of Castilla-La Mancha. Scholar Research in Marketing at Business Administration Department. Faculty of Social Sciences of Cuenca. University of Castilla-La Mancha (Spain). E-mail: Maria.Cordente@uclm.es.

Research Interest: Tourism marketing, consumer behavior and e-learning.

Juan-Antonio Mondéjar-Jiménez, PhD and Degree in Business Administration by University of Castilla-La Mancha. Degree in Advanced Studies in Marketing at the same university. Associate Professor in Marketing at Business Administration Department. Faculty of Social Sciences of Cuenca. University of Castilla-La Mancha (Spain). E-mail: JuanAntonio.Mondejar@uclm.es.

Research Interest: Consumer behavior, price perception, e-learning and tourism marketing.

Juan-Carlos Gázquez-Abad, $\mathrm{PhD}$ in Economics and Degree in Business Administration by University of Almeria. Associate Professor in Marketing at Business Department. Faculty of Economics and Business Administration. University of Almeria (Spain). E-mail: JCGazque@ual.es.

Research Interest: Retailing, sales promotions, consumer behaviour and agricultural marketing. 


\section{REFERENCES}

1. Asociación De Ferias Españolas (AFE) (2009): Estadísticas Ferias 2009. Retrieved October 8, 2010, from: http://www.afe.es/documentos/auditoria_AFE09.pdf

2. Asociación De Ferias Españolas (AFE) (2010): Utilidad de las ferias. Retrieved October 9, 2010, from: http://www.afe.es/sobre_las_ferias.htm

3. Gámir, A. (1999): "La actividad ferial y congresual en España”, Boletín de la A.G.E., n 28, pp. 39-60.

4. Gázquez, J. C. and Jiménez, J. F. (2002): "Las ferias comerciales en la estrategia de marketing: motivaciones para la empresa expositora", Distribución y Consumo, noviembre-diciembre, pp. 76-83.

5. Grupo Planner (2010): Cómo rentabilizar la participación en una feria. Retrieved October 10, 2010, from: http://www.gplanner.com/como_rentabilizar.pdf

6. Jiménez, J. F., Cazorla, I. M. and Linares, E. (2002): "Ferias comerciales en España: un análisis sectorial”, Distribución y Consumo, enero-febrero, pp. 61-71.

7. Jiménez, J. F. and Pemartín, M. (2008): “Análisis de la actividad ferial en España: la perspectiva sectorial de una década (1995-2005)", Distribución y Consumo, enero-febrero, pp. 51-71.

8. $\quad$ Kotler, P. (2006): Dirección de marketing. Madrid: Prentice Hall.

9. Marketing News (2006): "Fairs Allow Marketers to Spread Word to Large Audience", Marketing News, junio, núm. 15, pp. 11-13.

10. Munuera, J. L.; Ruiz, S.; Hernández, M. and Más, F., (1993): "Las ferias comerciales como variable de marketing: análisis de los objetivos del expositor”, Información Comercial Española, núm. 718, pp. 119137.

11. Muñiz, R. (2010): Marketing del siglo XXI. Madrid: Centro Estudios Financieros.

12. Navarro, F. (2001): Estrategias de marketing ferial. Madrid: ESIC.

13. Observatorio Turístico De Cuenca. Informes FITUR 2004-2008.

14. Purchalt, J. J. (2001): Las ferias comerciales como instrumento de Marketing al servicio de las empresas: Una aplicación a la Feria de Valencia. Doctoral thesis, University of Valencia (Spain).

15. Purchalt, J. J. (2008): "La actividad ferial en el contexto europeo", Distribución y Consumo, enero-febrero, pp. 29-50.

16. Rodríguez, I., De La Ballina, J. and Santos, L. (1997): Comunicación comercial: conceptos y aplicaciones. Madrid: Civitas.

17. Rubalcaba, L. and Cuadrado, J. R. (1994): "Urban hierarchies and territorial competition in Europe: exploring the role of fairs and exhibitions", Urban studies, vol. 32, n 2, pp. 379-400.

18. Stevens, R. P. (2005): Trade Show and Event Marketing. Thomson y American Marketing Association, Masson. 


\section{NOTES}

